\title{
IV. Blatizen.
}

\section{Weiblidie Ppramidenpappeln.}

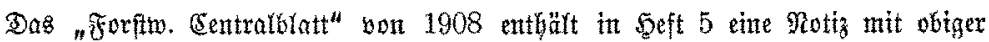

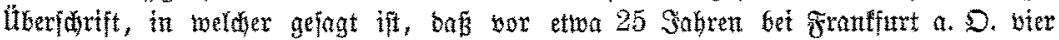
ältere weiblide Exemplare gefunben jeten uno baj exft feit biejer Beit veridiebene Baum=

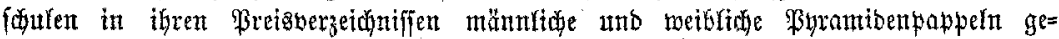
trentut fülorett.

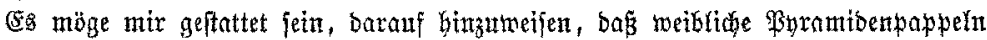
in Dentiditanb foron lange bor jener Franlfuter Entbefung befomt waren, went beren

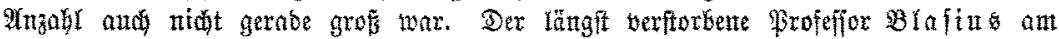

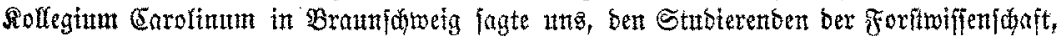
in feinem Bortrnge ither Botanif im Commer 1868, nfjo oor vierzig Sahren, Dá

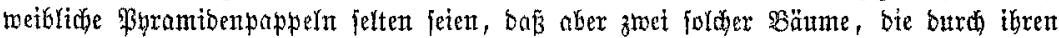

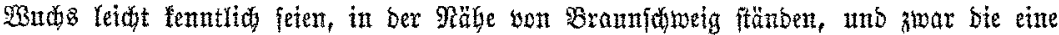

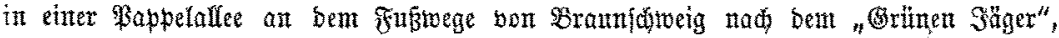

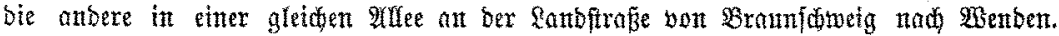
Sol babe beibe säume bet meinen Spaziergängen wieberfjolt gepehen; leibex fint jene

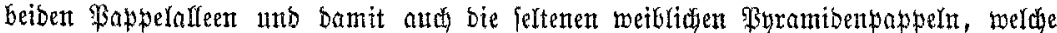

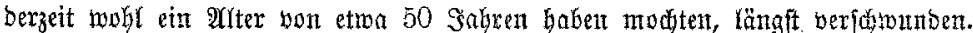

Forfmeifter Soreiber, Blantenburg= Garg.

\section{Godhidulnadhrichten.}

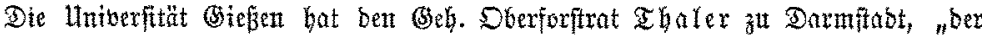
fid in mebr als 40 jâtbriger Bienftzeit burd exfolgreide Iatigfeit mb berborragenbe

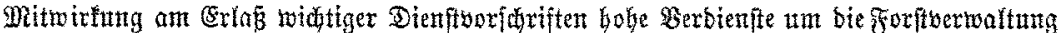

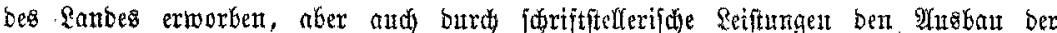

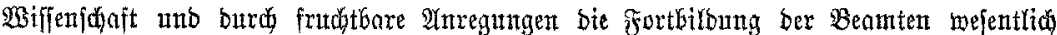

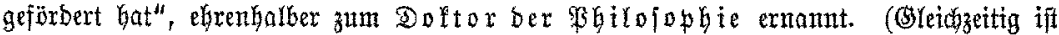

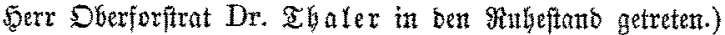

Profeffor Dr. Martin in IGaranbt wutre fïr bas näbfte Stubienjahr zum Rettor bex Mrfabentie gemäblt.

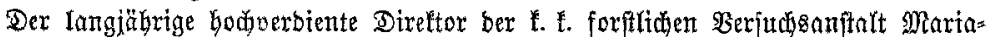

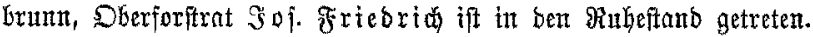

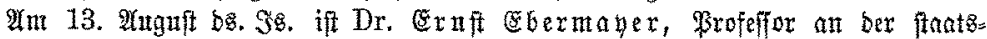

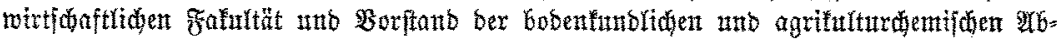

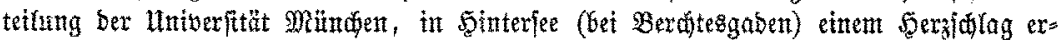
legen. Eit Mefrolog biejes berbienten Mannes toiro folgen. 